\title{
ANALISIS PERTUMBUHAN LABA PADA PERUSAHAAN SEKTOR PERTAMBANGAN YANG TERDAFTAR DI BURSA EFEK INDONESIA
}

\author{
Firman Mukhti Alamsyah $^{1^{*}}$, Nurjanti Takarini ${ }^{2}$ \\ ${ }^{12}$ Manajemen, Fakultas Ekonomi dan Bisnis, UPN “Veteran" Jawa Timur \\ Jl. Raya Rungkut Madya Gunung Anyar Surabaya 60294 \\ *Penulis Korespondensi; Email: firman.alamsyah2013@gmail.com², yayannurjanti.em@upnjatim.ac.id ${ }^{2}$
}

\begin{abstract}
Abstrak
Indonesia sangat kaya akan berbagai sumber daya, salah satunya adalah sumber daya alam yang salah satunya dapat dimanfaatkan dalam meningkatkan penerimaan negara bukan pajak. Selain itu juga dapat digunakan sebagai penunjang kegiatan perekonomian baik mikro maupun makro, oleh karena itu laba perusahaan digunakan untuk menunjang kegiatan operasional perusahaan dalam rangka mencapai tujuan perusahaan. Tujuan dari penelitian ini adalah untuk mengetahui pengaruh Likuiditas (Current Ratio), Leverage (Debt to Assets Ratio), Aktivitas (Total Assets Turnover) terhadap Pertumbuhan Laba. Teknik pengambilan sampel menggunakan purposive sampling yaitu pengambilan sampel berdasarkan kriteria, dari kriteria tersebut terdapat 25 sampel perusahaan pertambangan, dengan periode penelitian 2016-2018, dan teknik analisis data yang digunakan adalah Analisis Regresi Linier Berganda. Hasil observasi dapat disimpulkan bahwa variabel Current Ratio dan Debt to Assets Ratio memiliki hasil yang signifikan dengan arah hubungan negatif terhadap perusahaan sektor pertambangan yang terdaftar di BEI tahun 2016-2018, selain itu variabel Total Assets Turnover menunjukkan hasil yang tidak signifikan dan negatif untuk perusahaan sektor pertambangan yang terdaftar di BEI pada tahun 2016-2018.
\end{abstract}

Kata kunci: Likuiditas (CR), leverage (DAR), aktivitas (TAT), pertumbuhan laba.

\begin{abstract}
Indonesia is very rich in various resources, one of which is natural resources, one of which can be utilized in increasing non-tax state revenue. In addition, it can also be used as a support for economic activity both micro and macro, therefore company profits are used to support the company's operational activities in order to achieve the goals of the company. The purpose of this study was to determine the effect of Liquidity (Current Ratio), Leverage (Debt to Assets Ratio), Activities (Total Assets Turnover) on Profit Growth. The sampling technique used purposive sampling, namely sampling based on criteria, from these criteria there were 25 samples of mining companies, with a 2016-2018 research period, and the data analysis technique used was Multiple Linear Regression Analysis. The results of the observations can be concluded that the Current Ratio and Debt to Assets Ratio variables have significant results with a negative relationship direction to mining sector companies listed on the IDX in 2016-2018, besides that the Total Assets Turnover variable shows insignificant and negative results for mining sector companies listed on the IDX in 2016-2018.
\end{abstract}

Keywords: Liquidity (CR), leverage (DAR), activities (TAT), profit growth.

\section{Pendahuluan}

Pada dasarnya mengukur keberhasilan suatu perusahaan dalam menjalankan aktivitasnya seringkali berdasarkan tingkat perolehan laba yang di dapatkan. Salah satu tolak ukur dalam keberhasilan suatu perusahaan dapat dinilai dari seberapa baiknya kinerja manajemen keuangan untuk memperoleh besarnya 
laba perusahaan. Loss and profit statement ialah laporan keuangan yang menunjukan hasil kegiatan untuk memperoleh suatu keuntungan di masa tahun tertentu.

Di tahun 2016 ekonomi Indonesia masih bisa tumbuh tinggi, yaitu 5,02\% di tengah kondisi perekonomian global yang masih lesu. Sektor pertambangan bahkan mampu untuk kembali ke jalur positif (Chandra, 2017a). PT Aneka Tambang Tbk (Antam) mencatatkan kerugian sebesar Rp 496 miliar pada enam bulan pertama 2017. Emiten berkode ANTM itu sempat mencatatkan laba bersih pada kuartal 1 2017 sebesar Rp 6,64 miliar dan pada periode yang sama tahun lalu sebesar Rp 11 miliar (Chandra, 2017b).

Badan Pusat Statistik mengatakan pertumbuhan ekonomi nasional Indonesia di kuartal 12017 sebesar 5,01\%. Pada kuartal 12016 sebesar 4,92\%. Pertumbuhan ekonomi nasional didukung oleh beberapa lapangan usaha, tetapi bukan pertambangan yang justru mengalami penurunan sebesar $0,491 \%$. Dibandingkan dengan kuartal 42016 sektor pertambangan mengalami penurunan sebesar 0,78\% (Destrianita, 2017). Pada tahun 2018 perusahaan pertambangan mencatat pencapaian pendapatan negara bukan pajak sebesar Rp50 Triliun telah melampaui target pendapatan negara bukan pajak di tahun 2018 sebesar Rp 32,1 Triliun yang tercatat oleh Ditjen Minerba dan Kementerian ESDM (Hartomo, 2019).

Dengan demikian yang menyebabkan terjadinya penurunan pertumbuhan laba pada tahun 2017 yang disebabkan oleh beberapa faktor diantaranya beban penyelesaian pembangunan suatu pabrik, kebijakan tentang ekspor, menurunnya harga komoditi karena melimpahnya stok yang tersedia, serta adanya penurunan penjualan. Salah satu contohnya pada perusahaan aneka tambang yang diakibatkan dari menurunnya hasil penjualan dari Rp 4,16 Triliun tahun lalu, menjadi Rp 3,01 Triliun, sehingga penurunannya sebesar 27,66\% (Chandra, 2017b). Hal ini bisa menjadi salah satu faktor adanya penurunan pertumbuhan laba pada sektor pertambangan. Adapun data rata rata pertumbuhan laba perusahaan pertambangan yang terdaftar di BEI tahun 2016-2018 terdapat di Tabel 1.

\section{Tabel 1}

Rata-Rata Pertumbuhan Laba Perusahaan Sektor Pertambangan di BEI pada Tahun 2016-2018

\begin{tabular}{cccc}
\hline Tahun & $2016(\%)$ & $2017(\%)$ & $2018(\%)$ \\
\hline Rata-Rata Pertumbuhan Laba & $-47,292$ & $-4.205,409$ & 352,696
\end{tabular}

Berdasarkan Tabel 1 menunjukkan bahwa rata rata pertumbuhan laba perusahaan sektor pertambangan sangat berfluktuatif, tidak semuanya memiliki kinerja keuangan yang baik. Kinerja perumbuhan laba itu pun dapat dihitung menggunakan Earning After Tax tahun berjalan dikurangkan Earning After Tax tahun sebelumnya, berikut di bagi dengan Earning After Tax tahun sebelumnya kemudian dikalikan 100 persen. Terlihat dari Tabel 1 bahwa adanya rata-rata pertumbuhan laba yang fluktuatif dari $-47,292 \%$ kemudian mengalami penurunan drastis menjadi $-4.205,409 \%$, kemudian di tahun 2018 terjadi peningkatan pada pertumbuhan laba perusahaan sebesar $352,696 \%$.

Bermacam teknik analisis dapat dipakai untuk menghitung serta menginterpretasi kinerja manajemen keuangan serta labanya di antaranya dengan teknik analisis rasio keuangan, bertujuan untuk melihat kekuatan serta kelemahan keuangan perusahaan. Wibowo dan Pujiati (2011) mengelompokkan analisis rasio keuangan ke dalam empat kategori yaitu rasio likuiditas, rasio leverage, rasio aktivitas, dan rasio profitabilitas. Rasio Likuiditas (liquidity ratio) bertujuan perusahaan guna mengukur seberapa mampunya perusahaan memenuhi hutang jangka pendek. Rasio Likuiditas diukur dengan current ratio karena menunjukkan kesanggupan perusahaan untuk membayar hutang lancar dengan aset lancarnya. Rasio Aktivitas yang diukur dengan Total Assets Turnover yang menilai efektivitas perusahaan dalam menggunakan asetnya (Van Horne \& Wachowicz, 2012). Rasio Leverage yang diukur dengan Debt to Assets Ratio yaitu menjelaskan seberapa besar peusahaan ditanggung oleh hutang (Van Horne \& Wachowicz, 2012). Pertumbuhan laba ialah kenaikan ataupun penururnan laba dalam suatu periode. Dalam penelitian ini untuk mengukur pertumbuhan laba adalah Earning After Tax yang dipakai dikarenakan EAT merupakan net profit yang dapat digunakan untuk pembiayaan kegiatan operasi periode selanjutnya.

\section{Kajian Teoritis dan Hipotesis Pertumbuhan Laba}


Pertumbuhaan laba ialah menunjukkan naik atau turunnya laba dalam suatu masa. Laba yang dipakai adalah Earning After Tax(EAT), sebab Earning After Tax (EAT) merupakan pendapatan laba bersih yang bisa digunakan kembali untuk kegiatan operasi. Pertumbuhan Laba yang baik menandakan kinerja perusahaan yang baik juga, sehingga hal itu menjadi ukuran kinerja manajemen keuangan perusahaan, disebabkan semakin tumbuh laba, semakin baik juga kinerja manajemen. Kemudian bila perputaran financial perusahaan baik, perusahaan mengalami pertumbuhan laba yang baik juga.

\section{Likuiditas}

Menurut Kasmir (2010) rasio cepat (likuidity ratio) merupakan rasio dengan menilai sejauh mana perusahaan memenuhi hutang jangka pendeknya, maka perusahaan harus dapat mengelola hutang jangka pendeknya. Komponen pengukuran Likuiditas yang dipakai dalam riset ini guna mengukur kemampuannya yaitu Rasio Lancar (Curent Ratio), merupakan rasio untuk mengetahui kemampuan perusahaan membayar hutang lancar dengan aktiva lancar saat ditagih atau jatuh tempo secara keseluruhan (Kasmir, 2014).

\section{Leverage}

Rasio ini untuk mengukur seberapa besar aktiva dalam perusahaan didanai oleh utang. Atau seberapa besar hutang yang perusahaan tanggung dengan aktivanya (Kasmir 2010). Leverage diproksikan Debt to Aset Ratio ialah seberapa besar hutang perusahaan membiayai aktivanya. Apabila hasil rasio tinggi, mengindikasi pembiayaan dengan hutangnya juga semakin tinggi, lalu menjadi sebuah kesulitan untuk perusahaan dalam mendapat tambahan pinjaman yang berakibat kekawatiran perusahaan belum sanggup menutup hutang-hutangnya dengan aktiva perusahaannya.

\section{Aktivitas}

Rasio untuk mengukur keefektivitasan perusahaan dalam mengatur aktiva yang dipunyai dan mengukur efesiensi penggunaan sumber daya perusahaan (persediaan, penagihan piutang, penjualan, dll.) (Kasmir 2011). Aktivitas diproksikan dengan Rasio Total Asset Turnover mengukur berapa Rupiah aktiva dari tiap jumlah penjualan serta menghitung perputaran aktiva yang perusahaan miliki.

\section{Pengembangan Hipotesis \\ Pengaruh Likuiditas (Current Ratio) terhadap Pertumbuhan Laba}

Current Ratio merupakan salah satu bentuk rasio likuiditas. Kasmir (2010) menyatakan bahwa rasio lancar (Current Ratio) merupakan rasio untuk mengukur kemampuan perusahaan dalam memenuhi kewajiban jangka pendek atau utang yang segera jatuh tempo pada saat ditagih secara keseluruhan. Semakin tinggi Current Ratio suatu perusaha an akan semakin tinggi pula pertumbuhan laba dan sebaliknya semakin rendah Current Ratio suatu perusahaan akan semakin rendah pula pertumbuhan laba (Mahaputra, 2012). Menurut Sihombing (2018) menyatakan bahwa Currenr Ratio memiliki pengaruh negatif terhadap pertumbuhan laba. Pendapat tersebut di atas didukung penelitian Mahaputra (2012) dan Heikal, Khaddafi dan Ummah (2014) menunjukkan bahawa Current Ratio (CR) memiliki pengaruh terhadap pertumbuhan laba. Berdasarkan pendapat diatas maka dapat dihipotesiskan sebagai berikut:

$H_{l}$ : Likuiditas (Current Ratio) berpengaruh signifikan positif terhadap pertumbuhan laba.

\section{Pengaruh Leverage (Debt to Assets Ratio)) terhadap Pertumbuhan Laba}

Kasmir (2008) menyatakan apabila pembiayaan oleh hutang tinggi akan sulit juga pihak perusahaan untuk mendapat pinjaman, dikhawatirkan perusahaan tidak sanggup menutup hutangnya dengan aktiva yang dimiliki. Hal ini menunjukkan rasio DAR tinggi. Begitu juga apabila rasio DAR rendah, semakin minim perusahaan dibiayai oleh hutang. Menurut Gitta (2017), Debt to Assets Ratio berkontribusi terhadap pertumbuhan laba perusahaan, dengan Debt to Assets Ratio meningkat, maka profitabilitas perusahaan akan menurun karena meningkatnya hutang akan menyebabkan beban bunga semakin tinggi. Berarti Debt to Assets Ratio memiliki pengaruh signifikan negatif. Penelitian Wibisono (2016) dan Oktanto dan Amin (2014) menunjukkan bahwa Debt to Assets Ratio memiliki pengaruh terhadap pertumbuhan laba. Berdasarkan pendapat di atas, maka dapat dihipotesiskan sebagai berikut:

$\mathrm{H}_{2}$ : Leverage (Debt to Assets Ratio) berpengaruh signifikan negatif terhadap pertumbuhan laba.

\section{Pengaruh Aktivitas (Total Asset Turnover) terhadap Pertumbuhan Laba}


Menurut Van Horne dan Wachowicz (2005) Total Asset Turnover menjelaskan korelasi dari pendapatan bersih dengan total aktiva. TATO mencerminkan kemampuan modal yang diinvestasikan untuk menghasilkan "pengembalian" dari dana yang berada dalam keseluruhan aktiva beroperasi dalam suatu periode tertentu. Gunawan dan Wahyuni (2013) menyatakan TATO berdampak dan signifikan dengan arah hubungan positif pada pertumbuhan laba. Total Asset Turnover merupakan rasio untuk mengukur seberapa efisien seluruh aktiva perusahaan digunakan untuk menunjang kegiatan penjualan (Ghasempour \& Ghasempour, 2013), yang berarti semakin tinggi perputaran aktiva, maka akan semakin efisien dalam penggunaan aktiva peusahaan. Total Assests Turnover mencerminkan kemampuan perusahaan dalam mengukur tingkat efisiensi pemanfaatan sumber daya perusahaan dalam melaksanakan aktivitas sehari-hari. Total Asset Turnover yang semakin tinggi atau semakin efisien dalam penggunaannya makan menunjukkan pertumbuhan laba yang semakin tinggi pula, dan sebaliknya semakin rendah Total Assets Turnover maka semakin rendah juga pertumbuhan laba (Mahaputra, 2012). Berdasarkan pendapat di atas, maka dapat dihipotesiskan, sebagai berikut:

$H_{3}$ : Aktivitas (Total Asset Turnover) berpengaruh signifikan positif terhadap pertumbuhan laba.

\section{Metode Penelitian \\ Pertumbuhan Laba (Y)}

Menurut Harahap (2011), rasio yang menunjukkan perusahaan mampu menaikkan laba bersih dari tahun sebelum ialah rasio pertumbuhan laba. Dapat dihitung melalui rumus laba perusahaan masa sekarang dikurangi laba perusahaan masa sebelum, selanjutnya dibagi dengan laba perusahaan masa sebelumnya. Earning after tax adalah laba yang digunakan di penelitian ini.

$$
\text { Pertumbuhan laba }=\frac{Y_{t}-Y_{t-1}}{Y_{t-1}} \times 100 \%
$$

\section{Likuiditas $\left(X_{I}\right)$}

Likuiditas yaitu perusahaan mampu untuk memenuhi hutang lancarnya (Kasmir 2009). Rasio lancar (Current Ratio) yaitu rasio untuk mengukur seberapa mampu perusahaan memenuhi hutang lancar dengan aktiva lancar pada saat ditagih menyeluruh.

$$
C R=\frac{\text { Aktiva Lancar }}{\text { Hutang Lancar }} \times 100 \%
$$

\section{Leverage $\left(\mathrm{X}_{2}\right)$}

Leverage sebuah ukuran guna mengetahui mampukah perusahaan membayar hutang apabila perusahaan tersebut akan dilikuidasi (Kasmir, 2010). DAR ialah rasio untuk menghitung berapa besar total aktiva didanai oleh total hutang dengan kata lain berapa besar hutang yang persahaan miliki. Dihitung dengan rumus, sebagai berikut:

$$
\mathrm{DAR}=\frac{\text { Total Liabilitas atau Kewajiban }}{\text { Total Asset }} \times 100 \%
$$

\section{Aktivitas $\left(X_{3}\right)$}

Menurut Kasmir (2011), TATO ialah ukuran yang dipergunakan untuk menghitung tingkat efisiensi sumber daya perusahaan dapat dimanfaatkan (Halim, 2007). TATO dipergunakan untuk mengukur tingkatan efektivitas sumber daya aset. Dihitung dengan rumus berikut:

$$
T A T O=\frac{\text { Penjualan }}{\text { Total Aktiva }}
$$

\section{Populasi dan Sampel}

Populasi observasi ini adalah perusahaan pertambangan yang terdaftar di BEI tahun 2016-2018 yang berjumlah 48 perusahaan. Purposive sampling dipergunakan untuk teknik pengambilan sampel. Teknik pengambilan sampel yang berdasarkan kriteria, adalah sebagai berikut:

1. Perusahaan pertambangan yang menerbitkan laporan keuangan tiga tahun berturut-turut tahun 20162018 secara lengkap dengan mata uang dollar, dikarenakan nilai tukar rupiah terus berfluktuasi dengan tidak menentu, sehingga perusahaan merasa bahwa laporan keuangan yang disusun berdasarkan mata 
uang rupiah tidak mencerminkan posisi keuangan dan hasil operasi perusahaan, terutama bagi perusahaan yang transaksinya didominasi oleh mata uang selain rupiah.

2. Perusahan pertambangan yang memiliki laporan keuangan yang lengkap.

3. Perusahaan pertambangan yang tidak tersuspensi.

Berdasarkan kriteria di atas diperoleh 25 perusahaan yang sesuai, seperti yang ada di Tabel 2.

Tabel 2

Pemilihan Sampel

\begin{tabular}{lc}
\multicolumn{1}{c}{ Keterangan } & Jumlah Perusahaan \\
\hline Perusahaan pertambangan yang terdaftar di Bursa Efek Indonesia pada tahun 2016-2018. & 48 \\
Perusahaan yang memakai mata uang rupiah. & $(21)$ \\
Perusahan pertambangan yang tidak memiliki .laporan keuangan yang lengkap. & $(1)$ \\
Perusahaan pertambangan yang tersuspensi. & $(1)$ \\
Jumlah sampel penelitian. & 25 \\
\hline
\end{tabular}

Analisis Data dan Pembahasan Uji Outlier

Terdapat outlier apabila Mahal. Distance Maximum > Prob. dan Jumlah variabel $[=\mathrm{CHIINV}$ $(0,001 ; 4)$ : dicari melalui Excel] $=18,467$. Hasil analisis uji oulier penelitian ini menunjukkan nilai Mahalnya lebih kecil dari 18,467, yaitu 12,263 < 18,467. Dari data batasan tersebut, maka tidak ada yang outlier pada data, sehingga data memiliki kualitas yang baik, kemudian data ini bisa diteruskan untuk diolah lebih lanjut.

\section{Uji Normalitas}

Tabel 3

Uji Normalitas

\begin{tabular}{llccc}
\hline & & $X_{1}=\mathrm{CR}$ & $X_{2}=\mathrm{DAR}$ & $X_{3}=\mathrm{TATO}$ \\
\hline$N$ & & 75 & 75 & 75 \\
Normal Parameters & & 178,251200 & 55,257733 & 0,626480 \\
& Mean & 131,6671598 & 29,4749929 & 0,5305409 \\
Most Extreme Differences & Std. Deviation & 0,154 & 0,084 & 0,120 \\
& Absolute & 0,154 & 0,084 & 0,117 \\
& Positive & $-0,090$ & $-0,081$ & $-0,120$ \\
Test Statistic & Negative & 0,154 & 0,084 & 0,120 \\
Asymp. Sig. (2-tailed) & & $0,000^{\mathrm{c}}$ & $0,200^{\mathrm{c}, \mathrm{d}}$ & $0,010^{\mathrm{c}}$ \\
\hline
\end{tabular}

a. Test distribution is Normal.

b. Calculated from data.

c. Lilliefors Significance Correction.

d. This is a lower bound of the true significance.

Uji Kolmogorov-Smirnov dan Shapiro-Wilk data dipastikan dari populasi berdistribusi normal, jika nilai sig > 0,05 (5\%), sehingga menggunakan uji ini dihasilkan analisis bahwa variabel $\mathrm{CR}\left(X_{I}\right)=0,000$, dan TATO $\left(X_{3}\right)=0,010$, dari populasi dimana tidak berdistribusi normal, karena sig < 0,05 , sedangkan DAR $\left(X_{2}\right)=0,200$ berasal dari populasi berdistribusi normal. Hasil uji normalitas ada di Tabel 3 . Walaupun ada dua variabel yang berdistribusi normal, tetapi dari uji kualitas data (uji outlier) menunjukkan tidak ada outlier, dan dilihat dari "central limit of theorem" jumlah data yang diolah termasuk data besar, yaitu lebih dari 30. Dengan demikian dapat diasumsikan bahwa data dianggap berdistribusi normal.

\section{Uji Multikolinieritas}

\section{Uji Asumsi Klasik}

Pengujian multikolineritas kepada analisis regrresi linier berganda ini memiliki nilai VIF untuk variabel $C R\left(X_{1}\right)=1,511$, DAR $\left(X_{2}\right)=1,790$, dan TATO $\left(X_{3}\right)=1,317$, karena nilai VIF < 10 maka tidak adanya gejala multikolinieritas, dengan kesimpulan bahwa tidak terdapat multikolinieritas variabel dengan variabel bebas lainnya. Syarat multikolinieritas tinggi jika nilai VIF > 10 (Cryer \& Miller,1994). Hasil uji multikolinieritas dapat dilihat pada Tabel 4. 
Tabel 4

Uji Multikolinieritas

\begin{tabular}{llcc}
\hline \multirow{2}{*}{ Model } & \multicolumn{2}{c}{ Collinearity Statistics } \\
\cline { 3 - 4 } & (Colerance & VIF \\
\hline 1 & $X_{1}=$ CR & 0,662 & 1,511 \\
& $X_{2}=$ DAR & 0,559 & 1,790 \\
& $X_{3}=$ TATO & 0,760 & 1,317 \\
\hline
\end{tabular}

\section{Uji Heteroskedastisitas}

Menurut Gujarati (1995), untuk menguji ada atau tidaknya heteroskedastisitas digunakan uji-rank Spearman yaitu dengan mengkorelasikan variabel independen terhadap nilai absolut dari residual (error). Hasil mengetahui bahwa Sig. (2-tailed) rank Spearman pada variabel CR $\left(X_{1}\right)=0,098$, DAR $\left(X_{2}\right)=0,289$, dan TATO $\left(X_{3}\right)=0,656$, tidak memiliki hubungan signifikan antara residual bersama variabel independennya. Nilai signifikan masing-masing variabel $>0,05$, sehingga semua variabel yang tidak mempunyai hubungan yang signifikan. Hasil analisis ini memiliki kesimpulan bahwa tidak terjadi Heteroskedastisitas. Hasil uji Heteroskedastisitas dapat dilihat pada Tabel 5.

Tabel 5

Uji Heteroskedastisitas

\begin{tabular}{lllc}
\hline & & Unstandardized Residual \\
\hline Spearman's rho & Unstandardized Residual & Correlation Coefficient & 1,000 \\
& & Sig. (2-tailed) & 0,000 \\
& & $N$ & 75 \\
$X_{1}=\mathrm{CR}$ & Correlation Coefficient & 0,153 \\
& Sig. (2-tailed) & 0,098 \\
& $N$ & 75 & 0,124 \\
$X_{2}=\mathrm{DAR}$ & Correlation Coefficient & 0,289 \\
& Sig. (2-tailed) & 75 \\
& $N$ & 0,060 \\
& Correlation Coefficient & 0,656 \\
& Sig. (2-tailed) & 75 \\
\hline
\end{tabular}

*. Correlation is significant at the 0.05 level (2-tailed).

**. Correlation is significant at the 0.01 level (2-tailed).

\section{Uji Autokorelasi}

Adanya hubungan antara kesalahan pengganggu pada masa sekarang dengan kesalahan pengganggu masa sebelumnya. Jika data $>15$. Untuk asumsi klasik yang mengidentifikasi autokorelasi di sini tidak perlu dilakukan sebab data bukan data time series. Akan tetapi, jika uji autokorelasi tetap dilakukan, maka untuk asumsi klasik yang mengindentifikasi autokorelasi di sini menunjukkan hasil bahwa nilai DW sebesar 2,032 angka berada di daerah tidak adanya gejala Autokorelasi baik positif maupun sebaliknya, sehingga tidak ada gejala autokorelasi, Hasil uji autokorelasi dapat dilihat pada Tabel 6. Jadi dapat disimpulkan bahwa model regresi linier berganda yang diperoleh pada penelitian ini memenuhi asumsi klasik.

Tabel 6

$\underline{\text { Uji Autokorelasi }}$

\begin{tabular}{lccccc}
\hline \multirow{2}{*}{ Model } & $R$ & $R$ Square & Adjusted $R$ Square & Std. Error of the Estimate & Durbin-Watson \\
\hline 1 & $0,291^{\mathrm{a}}$ & 0,085 & 0,046 & 869,5130458 & 2,032 \\
\hline
\end{tabular}

a. Predictors: (Constant), $X_{3}=$ TATO, $X_{1}=\mathrm{CR}, X_{2}=\mathrm{DAR}$

b. Dependent Variable: $Y=$ Pertumbuhan Laba 


\section{Hasil Regresi Berganda}

\section{Uji Statistik}

Hasil regresi linier berganda dalam penelitian ini dapat dilihat pada Tabel 7.

Tabel 7

Hasil Regresi Berganda

\begin{tabular}{|c|c|c|c|c|c|}
\hline \multirow{2}{*}{\multicolumn{2}{|c|}{ Model }} & \multicolumn{2}{|c|}{ Unstandardized Coefficients } & \multirow{2}{*}{$t$} & \multirow{2}{*}{ Sig. } \\
\hline & & $B$ & Std. Error & & \\
\hline 1 & (Constant) & 1231,866 & 436,982 & 2,819 & 0,006 \\
\hline & $X_{1}=\mathrm{CR}$ & $-1,754$ & 0,944 & $-1,859$ & 0,067 \\
\hline & $X_{2}=\mathrm{DAR}$ & $-10,684$ & 4,588 & $-2,329$ & 0,023 \\
\hline & $X_{3}=\mathrm{TATO}$ & $-297,122$ & 218,613 & $-1,359$ & 0,178 \\
\hline
\end{tabular}

Dari hasil di atas dapat diuraikan dalam persamaan regresi linier berganda, yaitu sebagai berikut:

Pertumbuhan Laba $=\beta_{0}+\beta_{1} \mathrm{CR}+\beta_{2} \mathrm{DAR}+\beta_{3} \mathrm{TATO}+\mu_{i}$

Pertumbuhan Laba $=1231,866-1,754 \mathrm{CR}-10,604 \mathrm{DAR}-297,122 \mathrm{TATO}+\mu_{i}$

\section{Uji Hipotesis (Uji t)}

Uji $t$ untuk menunjukkan pengaruh variabel CR, DAR dan TATO secara parsial terhadap pertumbuhan laba

1. CR $\left(X_{I}\right)$ memiliki dampak negatif kepada Pertumbuhan Laba $(Y)$, diterima dengan tingkat [Sig. 0,067 < 0,1 : signifikan [negatif]

2. DAR $\left(X_{2}\right)$ memiliki dampak negatif kepada Pertumbuhan Laba $(Y)$, diterima dengan tingkat [Sig. 0,023 $<0,1$ : signifikan [negatif].

3. TATO $\left(X_{3}\right)$ tidak memiliki dampak negatif kepada Pertumbuhan Laba $(Y)$, atau tidak diterima dengan tingkat [Sig. 0,178>0,1] : tidak signifikan [negatif].

\section{Uji Kelayakan Model (Uji F)}

Uji $F$ untuk menunjukkan apakah semua variabel independen penelitian yang digunakan dalam model secara simultan dapat menjelaskan variabel dependennya. Hasil Uji $F$ dapat dilihat pada Tabel 8

Tabel 8

Hasil Perhitungan Uji $\boldsymbol{F}$

\begin{tabular}{ccccccc}
\hline Model & & Sum of Squares & $d f$ & Mean Square & $F$ & Sig. \\
\hline 1 & Regression & 4975208,989 & 3 & 1658402,996 & 2,194 & $0,096^{\mathrm{b}}$ \\
& Residual & 53679758,513 & 71 & 756052,937 & & \\
& Total & 58654967,502 & 74 & & & \\
\hline
\end{tabular}

a. Dependent Variable: $Y=$ Pertumbuhan Laba

b. Predictors: $($ Constant $), X_{3}=\mathrm{TATO}, X_{1}=\mathrm{CR}, X_{2}=\mathrm{DAR}$

Hasil analisis uji $F$ memberi hasil signifikan, karena signifikansinya kurang dari 0,1, yaitu 0,096 < 0,1, sehingga disimpulkan bahwa variabel independen CR, DAR dan TATO secara simultan dapat menjelaskan pertumbuhan laba.

\section{Uji Koefisien Detreminasi (R Square)}

Koefisien determinasi bertujuan untuk mengukur seberapa jauh kemampuan model dalam menerapkan variasi variabel dependen. Hasil uji koefisien detreminiasi ( $R$ Square) dapat dilihat pada Tabel 9.

Tabel 9

Hasil Koefisien Determinasi $\left(\boldsymbol{R}^{2}\right)$

\begin{tabular}{|c|c|c|}
\hline Model & $R$ & $R$ Square \\
\hline 1 & $0,291^{\mathrm{a}}$ & 0,085 \\
\hline
\end{tabular}


Hasil koefisien determinasi ( $R$ Square) mengartikan perubahan semua variabel CR $\left(X_{1}\right)$, DAR $\left(X_{2}\right)$, dan TATO $\left(X_{3}\right)$, bisa menerangkan bahwa perubahan variabel pertumbuhan laba $(Y)$. [lihat $R$ Square $0,085]$ atau $8,5 \%$ sisanya $91,5 \%$ [100\% - 8,5\%] diterangkan oleh variabel lainnya selain variabel CR $\left(X_{I}\right)$, $\operatorname{DAR}\left(X_{2}\right)$, dan TATO $\left(X_{3}\right)$.

\section{Pembahasan \\ Pengaruh Likuiditas (Current Ratio) terhadap Pertumbuhan Laba}

Hasil uji parsial (uji $t$ ) dapat diketahui bahwa variabel likuiditas yang diproksikan oleh Current Ratio (CR) berpengaruh negatif dan signifikan terhadap pertumbuhan laba. Hal ini dapat dilihat dari tingkat signifikansi yang dihasilkan yaitu 0,067. Tingkat signifikansi lebih kecil dari 0,1 dengan arah koefisien yaitu -1,754 menunjukkan bahwa variabel likuiditas memiliki pengaruh yang signifikan (negatif) terhadap pertumbuhan laba. Hasil ini sesuai dengan hipotesis 1 yang menyatakan bahwa likuiditas berpengaruh negatif terhadap pertumbuhan laba. Penelitian ini sejalan dengan penelitian yang dilakukan Mahaputra (2012), Heikal et al. (2014), dan Sihombing (2018) yang menyatakan bahwa Current Ratio (CR) berpengaruh signifikan negatif terhadap pertumbuhan laba.

Pengaruh hubungan negatif Current ratio dalam mempengaruhi pertumbuhan laba dikarenakan rata-rata current ratio perusahaan tambang 2016-2018 mengalami penurunan, sehingga adanya aktiva lancar perusahaan pertambangan yang terdaftar di Bursa Efek Indonesia tahun 2016-2018 mengalami penurunan berarti menandakan bahwa perusahaan kurang modal dalam membayar hutang (Kasmir, 2010). Aktiva lancar seharusnya digunakan untuk memberikan jaminan ketersediaan modal kerja, sehingga dapat mendukung kegiatan operasional atau melakukan investasi, namun perusahaan tidak mampu mengoptimalkan penggunaannya, sehingga membuat perusahaan tersebut akan kehilangan kesempatan memperoleh laba. Hal ini mengindikasikan bahwa kemampuan perusahaan dalam memenuhi kewajiban jangka pendeknya tidak memberikan jaminan ketersediaan modal kerja guna mendukung aktivitas operasional perusahaan, oleh karena itu perolehan laba yang ingin dicapai menjadi tidak seperti yang diinginkan. Selain itu perusahaan berusaha sebisa mungkin untuk menggunakan aktiva lancar bukan hanya untuk memenuhi utang tetapi juga untuk kepentingan yang lain.

\section{Pengaruh Leverage (Debt to Assets Ratio) terhadap Pertumbuhan Laba}

Hasil uji hipotesis (uji $t$ ) dapat diketahui bahwa variabel leverage yang diproksikan oleh Debt to Assets Ratio (DAR) berpengaruh negatif dan signifikan terhadap pertumbuhan laba. Hal ini dapat dilihat dari tingkat signifikansi yang dihasilkan yaitu 0,023 . Tingkat signifikansi lebih kecil dari 0,1 dengan arah koefisien yaitu -10,684 menunjukkan bahwa variabel leverage memiliki pengaruh yang signifikan (negatif) terhadap pertumbuhan laba. Hasil ini sesuai dengan hipotesis 2 yang menyatakan bahwa leverage berpengaruh negatif terhadap pertumbuhan laba. Penelitian ini sejalan dengan penelitian yang dilakukan Wibisono (2016) dan Oktanto dan Amin (2014), yang menyatakan bahwa leverage berpengaruh signifikan negatif terhadap pertumbuhan laba.

Pengaruh hubungan negatif dari debt to assets ratio dalam mempengaruhi pertumbuhan laba dikarenakan total liabilitas perusahaan pertambangan yang terdaftar di Bursa Efek Indonesia tahun 2016-2018 terbilang cukup tinggi berarti menjadikan sulit bagi perusahaan untuk mendapatkan tambahan pinjaman karena takut perusahaan tersebut tidak mampu menutupi hutang-hutangnya. Dengan demikian debt to assets ratio berkontribusi secara berlawanan terhadap pertumbuhan laba. Pengaruh debt to total asset terhadap pertumbuhan laba menunjukkan besar aktiva perusahaan dibiayai oleh utang yang digunakan perusahaan dapat membantu proses produksi untuk meningkatkan penjualan. Namun, bilamana perusahaan tidak mampu menutupi seluruh beban bunga yang harus dibayar karena hutang yang digunakan perusahaan terlalu tinggi, maka akan menyebabkan penurunan laba yang diperoleh perusahaan. Semakin tinggi hutang yang digunakan, mengakibatkan beban bunga juga akan semakin besar, sehingga mengurangi laba perusahaan.

\section{Pengaruh Aktivitas (Total Assets Turn Over) terhadap Pertumbuhan Laba}

Hasil uji hipotesis (uji $t$ ) dapat diketahui bahwa variabel aktivitas yang diproksikan oleh Total Asset Turnover (TATO) tidak memiliki pengaruh yang signifikan terhadap pertumbuhan laba. Hal ini dapat dilihat dari tingkat signifikansi yang dihasilkan yaitu 0,178 . Tingkat signifikansi lebih besar dari 
0,1 dengan arah koefisien yaitu -297,122 menunjukkan bahwa variabel aktivitas tidak memiliki pengaruh yang signifikan terhadap pertumbuhan laba. Hasil ini tidak sesuai dengan hipotesis 3 yang menyatakan bahwa aktivitas berpengaruh positif terhadap pertumbuhan laba. Penelitian ini sejalan dengan penelitian yang dilakukan Indriyani (2015) dan Oktanto dan Amin (2014) yang menyatakan bahwa aktivitas yang diukur dengan total asset turnover tidak memiliki pengaruh signifikan positif terhadap pertumbuhan laba.

Aktivitas dalam penelitian ini dapat diukur menggunakan total asset turnover yang merupakan perbandingan antara penjualan dengan total aktiva. Hasil penelitian ini tidak sesuai dengan teori yang menyatakan bahwa semakin tinggi total asset turnover maka semakin tinggi pula pertumbuhan laba. Tidak berpengaruhnya total asset turnover terhadap perubahan laba diakibatkan aktiva perusahaan digunakan untuk melakukan hal lain seperti ekspansi dan penambahan unit pada aktiva tetapnya. Selain itu tingkat penjualan berdasarkan total aktiva tidak memiliki pengaruh signifikan terhadap perubahan laba apabila dalam pemanfaatan keseluruhan aktiva yang tidak digunakan secara baik dan efektif, sehingga dapat mempengaruhi proses produksi dan penjualan dalam menghasilkan laba. Hal ini menunjukkan bahwa perputaran asset perusahaan terbilang belum efektif, sehingga belum bisa menghasilkan laba secara optimal. Apabila aktiva tersebut digunakan untuk menunjang kegiatan penjualan, maka akan menghasilkan laba. Dengan demikian semakin efektif perputaran asset atau pengelolaan asset perusahaan mampu menghasilkan kinerja perusahaan berupa pertumbuhan laba yang baik dan berdampak pada peningkatan tingkat pengembalian (return) yang didapat investor.

\section{Simpulan, Keterbatasan, dan Saran Simpulan}

Current ratio memberikan konstribusi dengan hasil yang berlawanan pada hasil pertumbuhan laba. Semakin rendah current ratio semakin tinggi pula pertumbuhan laba pada sektor perusahaan pertambangan yang terdaftar di BEI 2016-2018. Debt to Assets Ratio memberikan kontribusi dengan hasil yang berlawanan pada hasil pertumbuhan laba. Semakin rendah $D A R$ mengindikasikan semakin tinggi variabel dependen pertumbuhan laba perusahaan pertambangan yang terdaftar di BEI 20162018. Total Assets Turnover tidak memberikan kontribusi kepada pertumbuhan laba pada perusahaan pertambangan yang terdaftar di BEI 2016-2018, sehingga seberapapun tinggi atau rendahnya TATO tidak selalu diikuti dengan pertumbuhan laba.

\section{Keterbatasan}

Data penelitian yang digunakan hanya terbatas dari tahun 2016-2018 saja. Oleh karena itu, untuk dapat mendeskripsikan kondisi terkini, maka data penelitian seharusnya diperluas sampai dengan tahun 2020 .

\section{Saran}

Adapun beberarapa saran yang dapat diberikan kepada para pihak seperti berikut ini. Bagi perusahaan sebaiknya mengoptimalkan kemampuan tata kelola pendapatan yang stabil supaya mampu mepertahankan tingkat profit perusahaan, dan perusahaan harus juga. dapat mengelola aktivitasnya terutama perputaran aktiva. Bagi peneliti berikut sebaiknya juga memperhatikan variabel lain yang di luar dari ke tiga variabel, karena pengaruh dari ketiga variabel yang hasilnya hanya sebesar $8,5 \%$. Di antaranya variabel yang diluar dari ketiga variabel yaitu rasio pasar, rasio keuangan yang lain dan kebijakan deviden dalam. Serta teknik pengambilan sampel tidak dipisahkan baik mata uang Dollar maupun Rupiah.

\section{Referensi}

Cryer, J. D., \& Miller, R. B. (1994). Statistics for business: Data analysis and modeling (Duxbury series in business statistics \& decision sciences). USA: South-Western.

Chandra, A. A. (2017a). Sektor pertambangan kembali bergairah di 2016. Detik.com. Diunduh dari https://finance.detik.com/berita-ekonomi-bisnis/d-3414729/sektor-pertambangan-kembalibergaira h-di-2016

(2017b). Antam rugi Rp 496 Miliar di semester I-2017. Detik.com. Diunduh dari https:// finance. detik.com/bursa-dan-valas/d-3627252/antam-rugi-rp-496-miliar-di-sem ester-i-2017 
Destrianita (2017). BPS: Sektor pertambangan mengalami penurunan pada kuartal I 2017. Tempo.co. Diunduh dari https://bisnis.tempo.co/read/872542/bps-sektor-pertambangan-mengalami-penur unan -pada-kuartal-i-2017/full\&view=ok

Ghasempour, A., \& Ghasempour, M. (2013). The relationship between operational financial ratios and firm's abnormal stock returns. Research Journal of Applied Sciences, Engineering and Technology, 15, 2839-2845. http://dx.doi.org/10.19026/rjaset.6.3794

Gujarati, D. (1995). Ekonometrika dasar. Edisi Bahasa Indonesia. Penerjemah Sumarno Zain. Jakarta: Penerbit Erlangga.

Gunawan, A., \& Wahyuni, S. F. (2013). Pengaruh rasio keuangan terhadap pertumbuhan laba pada perusahaan perdagangan di Indonesia. Jurnal Ilmiah Manajemen dan Bisnis, 13 (1), 63-84. https:// doi.org/10.30596/jimb.v13i1.102

Halim, A. (2007). Manajemen keuangan bisnis. Bogor: Ghalia Indonesia.

Harahap, S. (2011). Analisis kritis atas laporan keuangan. Jakarta: PT. Raja Grafindo Persada.

Hartomo, G. (2019). Lampaui target, PNBP sektor pertambangan 2018 capai Rp50 Triliun. Okezone.com. Diunduh dari https://economy.okezone.com/read/2019/01/09/20/2002050/lampa ui-targ et-pnbp-sektor-pertambangan-2018-capai-rp50-triliun

Heikal, M., Khaddafi, M., \& Ummah, A. (2014). Influence analysis of return on assets (ROA), return on equity (ROE), net profit margin (NPM), debt to equity ratio (DER), and current ratio (CR), against corporate profit growth in automotive in Indonesia Stock Exchange. International Journal of Academic Research in Business and Social Sciences, 4(12), 101-114. http://dx.doi. org/10.6007/ IJARBSS/v4-i12/1331

Indriyani, I. (2015). Pengaruh rasio keuangan terhadap pertumbuhan laba pada perusahaan pertambangan yang terdaftar di BEI. Jurnal Manajemen dan Bisnis Sriwijaya, 13(3), 343-358. https:// doi.org/ 10.29259/jmbs.v13i3.3378

Kasmir (2008). Analisis laporan keuangan. Jakarta: Rajawali Pers (2009). Analisis laporan keuangan. Jakarta: Rajawali Pers (2010). Analisis laporan keuangan. Jakarta: PT Raja Grafindo Persada. (2011). Analisis laporan keuangan. Jakarta: PT Raja Grafindo Persada. (2014). Analisis laporan keuangan. Jakarta: PT Raja Grafindo Persada.

Mahaputra, I. N. K. A. (2012). Pengaruh rasio-rasio keuangan terhadap pertumbuhan laba pada perusahaan manufaktur yang terdaftar di BEI. Jurnal Akuntansi dan Bisnis, 7(2), 243-254.

Oktanto, D., \& Amin, M. N. (2014). Pengaruh rasio keuangan terhadap perubahan laba pada perusahaan manufaktur yang terdaftar di Bursa Efek Indonesia (BEI) Tahun 2008-2011. Jurnal Akuntansi Trisakti, 1(1), 60-77.

Sihombing, H. (2018). Pengaruh current ratio dan debt to equity ratio terhadap pertumbuhan laba pada perusahaan property dan real estate yang terdaftar di BEI periode 2010-2014. Jurnal Media Studi Ekonomi, 21(1), 1-14.

Van Horne, J. C., \& Wachowicz, J. M. (2005). Prinsip-prinsip manajemen keuangan. Buku Satu. Edisi 12 (Ahli Bahasa: Dewi Fitriasari \& Deny Arnos). Jakarta: Salemba Empat.

------ (2012). Prinsip-prinsip manajemen keuangan. Edisi 13. Jakarta: Salemba Empat.

Wibisono, S. A. (2016). Pengaruh kinerja keunagan terhadap pertumbuhan laba pada perusahaan otomotif di BEI. Jurnal Ilmu dan Riset Manajemen, 5(12), 1-24.

Wibowo, H. A., \& Pujiati, D. (2011). Analisis rasio keuangan dalam memprediksi perubahan laba pada perusahaan real estate dan property di Bursa Efek Indonesia (BEI) dan Singapura (SGX). The Indonesian Accounting Review, 1(02), 155-160. 